No reports of fungus damage to unprocessed wool have been found in the literature, although several unidentified actinomycetes have been shown to be capable of bringing about a rapid disintegration of wool fibres while still on the sheep ${ }^{1}$, and this present report indicates a further source of damage by a group of organisms that has been little studied in relation to the fleece.

Further investigations into the methods of spread of the fungus and its infection of wool are in progress and a full account will be published elsewhere. A. P. Mulcock

Canterbury Agricultural College,

University of New Zealand, Christchurch.

Feb. 4.

${ }^{1}$ Philipson, Melva N., Nature, 180, 1205 (1957).

\section{Abnormal Development of the Basis in Balanus amphitrite var. stutsburi Darwin}

THE deformation of barnacle shells by growth on unfavourable substrates is now well known ${ }^{1,2}$. The distinctive scalloped form of basis produced on toxic anti-fouling paints has been illustrated by these and other authors. The same deformity occurs when settlement takes place on a toxic metal surface, for example, the copper sheathing of a wooden hull.

Recent examination of some specimens of Balanus amphitrite var. stutsburi Darwin from "West Africa" in the City Museum, Bristol, dating from the midnineteenth century and conceivably belonging originally to Samuel Stutchbury, showed that four of the five specimens handled have this deformed basis (Fig. 1). The fifth is regular in outline except where distorted by two small encrusting oyster shells. Spectrographic examination of green material in the erevices of the contorted bases indicated a high percentage of copper. No copper was associated with the other smooth-shelled specimen. Nor was any found in the glue used to secure the specimens to the display 'tablet'. It is practically certain therefore that the deformed specimens are derived from the bottom of a copper-sheathed ship on which they arrived in Great Britain, presumably from West Africa, the home of this variety.

In the Darwin cirripede material in the British Museum (Natural History) there are mounted on a tablet, among other named varieties, eight numbered

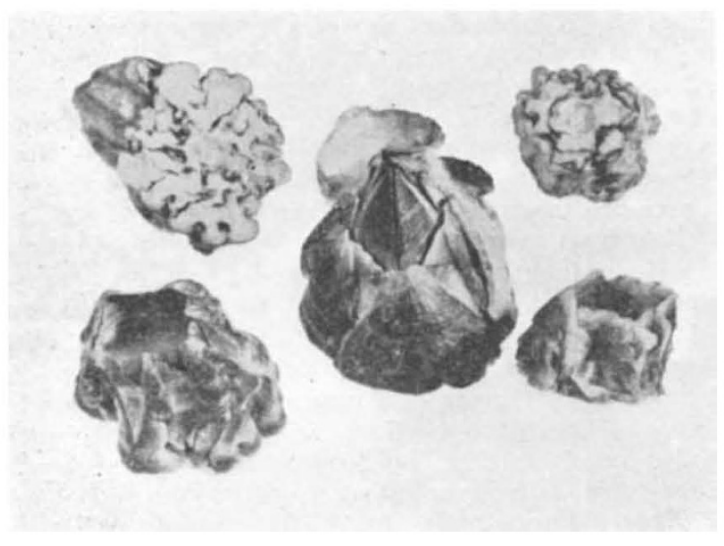

Fig. 1. B. amphitrite stutsburi Darwin. Four deformed specimens from a copper substrate and one normal smooth-walled specimen. (Bristol City Museum Collection) specimens assigned to $B$. a. stutsburi in a manuscript list in Darwin's hand. Of these, five are distorted specimens, one (No. 18 on the tablet) possibly the original of Darwin's illustration of the variety (Pl. V, Fig. 2d) ${ }^{3}$. Thus Darwin illustrated a deformed specimen only while also having normal material before him. This is still the only illustration of the complete shell of $B$. a. stutsburi.

Current examination of a large collection of new material of the variety from West Africa has shown that the rugged or deformed type figured by Darwin does not occur on natural and non-toxic substrates, for example, shells, stones, wood, concrete and iron. and that stutsburi is normally a smooth variety of $B$. amphitrite in its natural habitat.

The form and variability of this and some other varieties of $B$. amphitrite will be discussed at greater: length in subsequent papers to be published, in collaboration, elsewhere.

I am indebted to the Director, City Museum, Bristol. for the loan of the specimens figured here, to my colleague, Mr. L. G. Young, for the spectrographic examinations of the copper-containing inclusions from the bases, and to the Director, British Museum (Natural History), for permission to examine the Darwin and other material in that Museum.

\section{H. G. STuBbings}

Admiralty Materials Laboratory,

Holton Heath,

Poole, Dorset. Feb. 24.

${ }^{1}$ Pomerat, C. M., and Weiss, C. M., Biol. Bull., 91, 57 (1946).

'Weiss, C. M., Ecology, 29, 116 (1948).

"Darwin, C., "Monograph of the Cirripedia, Balanidae" (Ray Society, London, 1854)

\section{A Quantitative Serum-Agar Technique}

WHILE investigating the changes which occur in plant cytoplasmic proteins during growth and differentiation, using the Ouchterlony serum - aggar plate technique ${ }^{1}$, the need arose for a quantitative method of estimating the protein constituents. Although there are several methods available ${ }^{2-7}$, none of them is easily applicable to a multi-antigenic system, and in addition the concentrations of the proteins can only be estimated separately, even under favourable conditions, at \pm 10 per cent and moro usually \pm 50 per cent.

With the method described here it has been possible, with the system studied, to estimate the relative protein concentration within \pm 4 per eent, and it is probable that the technique could be developed to limits of \pm 2 per cent. The sensitivity of the technique is dependent on at least three factors : standardization of procedure; the titre of the individual protein or proteins; and the accuracy with which one can pipette the small volumes of liquid which have to be used when the antiserum, and sometimes the antigen solution, is in short supply.

The method consists of titrating antigen on to antibody and following the titration on a modified Ouchterlony plate. Two end-points are obtained (Fig. 1) : (a) where free antibody is just detectable ; (b) where free antigen is just detectable.

The technique is as follows : into a series of small tubes is pipetted a standard volume of antiserum $(0.1 \mathrm{ml}$. of monospecific siderophilin antiserum was used in these experiments). To each of these is added the same volume of antigen in a series of different concontrations (normal human serum diluted 